\title{
Pengaruh Promosi dan Kualitas Pelayanan terhadap Kepuasan Konsumen pada Pembelian Tiket Pesawat Garuda pada PT. Hamsa \\ Tour and Travel (Studi kasus Pada Pembelian Tiket Medan- Jakarta)
}

\author{
Azmi Fauzi \\ Universitas Prima Indonesia \\ azmifauzi97@gmail.com \\ Kurniawan Sarlo \\ Universitas Prima Indonesia \\ kurniawansarlo@yahoo.com
}

\author{
Kenny \\ Universitas Prima Indonesia \\ muliakenny@gmail.com \\ Jarungjung Hutagaol \\ Universitas Prima Indonesia \\ jarungjung13@gmail.com

\section{Made Adhiguna Samvara \\ Universitas Prima Indonesia madhiguna@yahoo.com}

\begin{abstract}
Abstrak Jasa harus dapat memuaskan keinginan dan kebutuhan konsumen karena produk yang ditawarkan pada dasarnya tidak berwujud. Jasa yang diberikan oleh produsen kepada konsumen akan bermanfaat apabila dapat memenuhi kebutuhan konsumen tersebut. Masyarakat sebagai konsumen tentu selalu mengharapkan adanya pelayanan yang baik dalam usaha memenuhi kebutuhan dan keinginannya. Pemenuhan kebutuhan dan keinginan tersebut harus diiringi oleh tingkat kepuasan agar terciptanya tingkat pembelian. Oleh sebab itu peneliti ingin melakukan penelitian terhadap PT. Hamsa and Tour Travel, sebab perusahaan tersebut termasuk perusahaan yang bergerak di bidang jasa. Tujuan penelitian ini adalah untuk menguji dan menganalisis pengaruh Promosi dan Kualitas Pelayanan Terhadap Kepuasan Konsumen Pada Pembelian Tiket Pesawat Garuda Pada PT. Hamsa Tour and Travel. Metode yang digunakan adalah analisis regresi linear berganda. Populasi berjumlah 129 konsumen dan sampel dalam penelitian berjumlah 98 konsumen. Hasil perhitungan pengujian secara parsial dan secara simultan Promosi dan Kualitas Pelayanan berpengaruh positif dan signifikan Terhadap Kepuasan Konsumen Pada Pembelian Tiket Pesawat Garuda Pada PT. Hamsa Tour and Travel. Besar koefisien determinasi diperoleh sebesar 31,5\% dari variasi variabel dependen yaitu Kepuasan Konsumen yang dapat dijelaskan oleh variasi variabel
\end{abstract}


independen Promosi dan Kualitas Pelayanan sedangkan sisanya sebesar $68,5 \%$ dijelaskan oleh variabel lain yang tidak diteliti pada penelitian ini, seperti harga, citra merek dan sebagainya.

\section{Kata Kunci Promosi, Kualitas Pelayanan, Kepuasan Konsumen}

\section{PENDAHULUAN}

Kecenderungan konsumen merasa kurang puas terhadap kualitas jasa transportasi di dasarkan pada beberapa faktor diantaranya meliputi tidak tersedianya informasi dalam pelayanan yang cepat dan tepat kepada konsumen. Hal ini juga menjadi bahan pertimbangan bagi masyarakat konsumen pada umumnya berkaitan kurang memuaskannya kualitas pelayanan jasa transportasi sehingga memperngaruhi kepuasan konsumen.

Perusahaan melakukan promosi untuk menarik konsumen. Dengan adanya promosi diharapkan konsumen melakukan keputusan pembelian baik untuk yang pertama kali membeli maupun pembelian ulang. Disinilah perlunya mengadakan promosi yang terarah, karena diharapkan dapat memberikan pengaruh positif terhadap meningkatnya penjualan. Dengan promosi yang baik diharapkan akan terjadi komunikasi antara produsen dan konsumen. Kemudian dengan adanya komunikasi tersebut diharapkan dapat memperoleh konsumen baru dan mempertahankan konsumen lama.

PT. Hamsa Tour and Travel bergerak di bidang jasa transportasi yang menyelenggarakan perjalanan serta bertindak sebagai perantara di dalam menjual produk dan mengurus jasa untuk melakukan perjalanan domestik maupun internasional, dan juga melayani reservasi hotel. Perusahaan menawarkan produk yaitu menjual tiket pesawat untuk penerbangan Garuda Indonesia Airlines, Lion Airlines, Sriwijaya Airlines dan Air Asia.

Proses pelayanan adalah memastikan bahwa konsumen puas dengan cara melakukan pengecekan setelah penerimaan barang dan setelah melakukan service kepada perusahaan. Pelayanan kebanyakan dengan menghubungi pelanggan via telepon kantor atau handphone pribadi para salesman. Apabila ada yang bermasalah atau keluhan konsumen maka akan disampaikan kepada salesman by phone atau melalui kotak saran yang tersedia di sekitar perusahaan. Setiap bulannya perusahaan melakukan rekapan keluhan yang dilakukan konsumen dan melakukan perbaikan secara berskala terhadap keluhan dari konsumen. Pencatatan keluhan selalu di rekapitulasi setiap sebulan sekali dan diberikan kepada Kepala Operasional untuk dianalisa dan kemudian dibahas pada rapat mengenai permasalahan dan perbaikan keluhan pelanggan ini sehingga kualitas pelayanan yang diberikan dapat memuaskan pelanggan.

\section{Landasan Teori}

\subsection{Promosi}

Menurut Hasan (2014: 603), promosi merupakan fungsi pemasaran yang fokus untuk mengkomunikasikan program-program pemasaran secara persuasif kepada target pelanggan atau calon pelanggan untuk mendorong terciptanya transaksi-pertukaran antara perusahaan dan pelanggan. 
Menurut Morissan (2010: 25), promosi merupakan elemen atau bagian dari pemasaran yang digunakan perusahaan untuk berkomunikasi dengan konsumennya.

Menurut Abdurrahaman (2015:156), komunikasi pemasaran atau promosi adalah satu bauran pemasaran yang digunakan untuk meningkatkan nilai pelanggan atau membangun ekuitas merek dalam ingatan pelanggan.

Dari uraian diatas dapat disimpulkan, promosi merupakan kegiatan yang direncanakan dengan maksud membujuk, merangsang konsumen agar mau membeli produk perusahaan sehingga tujuan untuk meningkatkan penjualan diharapkan dapat tercapai.

Menurut Abdurrahman (2015:165), dalam merancang bauran promosi banyak alat-alat yang seharusnya dipergunakan :

1. Periklanan (advertising)
a. Penampilan public
b. Daya serap
c. ungkapan perasaan yang jelas
d. menanamkan citra
e. Jangkauan luas

2. Penjualan tatap muka (personal selling)
a. berhadapan langsung secara pribadi
b. keakraban
c. tanggapan

3. Promosi penualan (sales promosi)
a. komunikan
b. mengertak
c. instansi

4. Publitas (publicity)

a. nilai kepercayaan yang tinggi

b. mempunyai dorongan ke luar yang bisa menjangkau lebih banyak

c. mempunyai potensi untuk mendramtisasikan perusahaan atai produk

5. Hubungan masyarakat (public relation)

Dapat memengaruhi sikap atau perilaku khalayak embeli karena tidak hanya mengunakan media tetapi juga kemampuan tenga terampil.

6. Pemasaran langsung (direct marketing)

Aktivitas promosi yang dilakukan untuk mendapatkan pesanan langsung dari konsumen.

\subsection{Kualitas Pelayanan}

Menurut Tjptono dan Chandra (2012:74), Kualitas Pelayanan mencerminkan semua dimensi penawaran produk yang menghasilakn manfaat bagi pelanggan

Menurut Abdullah dan Tantri (2014;44), Kualitas pelayanan adalah keseluruhan ciri dan karakteristik suatu barang atau jasa yang berpengaruhi pada kemampuannya untuk memuaskan kebutuhan yang dinyatakan maupun yang tersirat.

Berdasarkan beberapa pengertian di atas dapat disimpulkan kualitas pelayanan adalah semua tindakan atau kinerja yang dapat di tawarkan oleh perusahaan kepada pelanggan yang pada intinya tidak terwujud dan tidak menghasilkan kepemilikan apapun namun dapat dirasakan manfaatnya oleh pelanggan. 
Menurut Sunyoto (2013 : 145), dalam pelayanan kepada pelanggan, ada beberapa unsur pelayanan yang harus diperhatikan seorang produsen yaitu:

1. Fasilitas fisik. Indikatornya: peralatan dan fasilitas yang lengkap dan nyaman, gedung atau kantor yang memadai dan nyaman serta petugas yang ramah, sopan dan rapi.

2. Keandalan. Indikatornya: ketepatan pelaksanaan layanan, kesesuaian pelasanaan dengan prosedur dan konsisten tidak pilih kasih.

3. Kesigapan pelayanan dan kecepatan. Indikatornya: kecekatan petugas dalam pelayanan, hemat waktu dan tenaga.

4. Kepastian. pelayanan Indikatornya: kemampuan petugas, keramahan petugas, kepercayaan pelanggan dan keamanan pelanggan.

5. Kemudahan. Indikatornya : kemudahan memperoleh pelayanan, kejelasan informasi dan pemahaman pelanggan

\subsection{Kepuasan}

Menurut Kotler (2012: 42), Kepuasan konsumen adalah perasaan senang atau kecewa seseorang yang berasal dari perbandingan antara kesannya terhadap kinerja (atau hasil) suatu produk dan harapan-harapannya.

Menurut Sangadji dan Sopiah (2013:180), kepuasan atau ketidakpuasan adalah perasaan senang atau kecewa seseorang yang berasal dari perbandingan antara kesannya terhadap kinerja produk yang riil atau aktual dengan kinerja produk yang diharapkan.

Menurut Assauri (2014:176), kepuasan konsumen merupakan ukuran keberhasilan strategi pemasaran perusahaan dalam memasarkan produk.

Berdasarkan definisi-definisi di atas, dapat disimpulkan bahwa kepuasan konsumen adalah perasaan seseorang yang muncul berdasarkan perbandingannya antara kesannya dengan kinerja produk yang digunakan dan pelayanan sesuai dengan yang diharapkan konsumen.

Menurut Hasan (2013:106-107), mengemukakan ada empat metode untuk mengukur kepuasan pelanggan yaitu sebagai berikut :

1. Sistem keluhan dan saran. Organisasi yang berorientasi pelanggan memberikan kesempatan kepada pelanggan untuk menyampaikan saran secara langsung.

2. Ghost shopping, Metode ini efektif jika para manajer perusahaan bersedia sebagai ghost shoppers untuk mengetahui secara langsung bagaimana karyawannya berinteraksi dan memperlakukan pelanggan.

3. Lost customer analysis, Perusahaan menghubungi para pelanggan yang telah berhenti membeli atau yang berahli pemasok, agar dapat memahami mengapa berhenti atau pindah pemasok.

4. Survei kepuasan pelanggan. Melalui survei, perusahaan akan memperoleh tanggapan langsung dari pelanggan

\subsection{Kerangka Konseptual}

Promosi dilakukan dengan tujuan untuk mengingatkan kembali pelanggan atas keuntungan dan kegunaan produk. Dengan adanya promosi yang dilakukan perusahaan maka pelanggan dapat memperoleh informasi produk dan dapat memberikan kepuasan.Promosi dapat menarik perhatian pelanggan dan menciptakan kepuasan. Kualitas pelayanan bisa di artikan sebagai ukuran seberapa bagus tingkat layanan yang diberikan oleh perusahaan da mampu sesuai dengan ekspetasi dari pelanggan/konsumen. 
Konsumen akan merasa puas jika produk atau jasa yang di pakainya mendapat service/ layanan yang baik. Pelayanan yang baik membuat konsumen menjadi nyaman dan mungkin akan kembali menggunkan produk/jasa yang ditawarkan oleh perusahaan sehingga akan menjadi pelanggan.

Dari pernyataan di atas, kerangka konseptual yang dapat dikembangkan oleh peneliti adalah sebagai berikut:

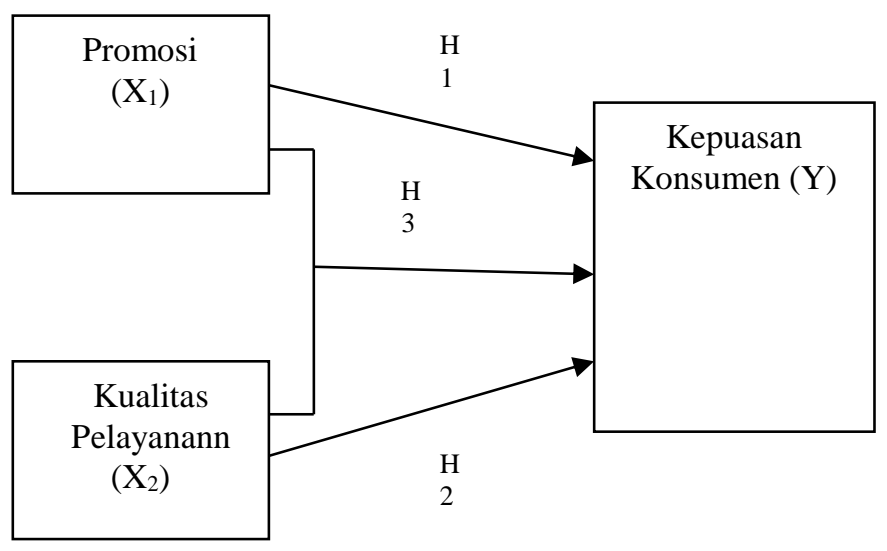

\section{Hipotesis Penelitian}

Adapun hipotesis yang diajukan dalam penelitian ini yaitu:

H1: Promosi mempengaruhi secara parsial terhadap kepuasan konsumen pada PT. Hamsa Tour and Travel

H2: Kualitas pelayanan secara parsial terhadap Kepuasan Konsumen pada PT. Hamsa Tour and Travel

H3: Promosi dan kualitas pelayanan mempengaruhi secara simultan terhadap kepuasan konsumen pada PT. Hamsa Tour and Travel

\section{METODOLODI PENELITIAN}

Populasi berjumlah 129 pelanggan. Jumlah sampel yang digunakan oleh peneliti adalah 98 pelanggan dan 30 pelanggan digunakan untuk uji validitas yang diambil diluar dari sampel. Teknik analisis data yang digunakan adalah analisis regresi linear berganda setelah memenuhi asumsi klasik yang menyangkut uji normalitas, multikolinearitas, dan heterokedastisitas. Penarikan kesimpulan hipotesis dilakukan dengan cara uji t dan uji $\mathrm{F}$ pada level signifikansi 5\%. Keseluruhan tabulasi dan pengelolaan data menggunakan software SPSS.

\section{HASIL PENELITIAN}

\subsection{Hasil Uji Validitas}

Hasil uji validitas dilakukan untuk mengetahui apakah instrumen dari penyataan yang digunakan valid dan dapat digunakan dalam penelitian ini. Hasil pengujian dengan membandingkan $r$ tabel terhadap $r$ hitung. Nilai $r$ hitung pada setiap pernyataan yang diuji lebih besar dari $\mathrm{r}$ tabel, dapat disimpulkan bahwa pernyataan tersebut valid dan dapat digunakan dalam penelitian. 


\section{Tabel 4.1}

Uji validitas

\begin{tabular}{|c|c|c|c|c|}
\hline & Variabel & $\begin{array}{c}\text { N of } \\
\text { Items }\end{array}$ & $\begin{array}{c}\text { Jumlah } \\
\text { Kuesioner Valid }\end{array}$ & Keterangan \\
\hline 1 & Promosi & 8 & 8 & Valid \\
\hline 2 & Kualitas Pelayanan & 8 & 8 & Valid \\
\hline 3 & Kepuasan Konsumen & 8 & 8 & Valid \\
\hline
\end{tabular}

Sumber: Data primer yang diolah,2019

Berdasarkan Tabel 4.1 nilai $r$ hitung pada setiap pernyataan yang diuji lebih besar dari $r$ tabel, sehingga dapat disimpulkan bahwa pernyataan tersebut valid dan dapat digunakan dalam penelitian.

\subsection{Hasil Uji Reliabilitas}

Hasil uji reliabilitas digunakan untuk mengukur seberapa jauh konsisten alat ukur untuk dapat memberikan hasil yang sama dalam mengukur suatu hal yang sama. Hasil pengujian dengan melihat hasil nilai crobanch alpha harus lebih besar dari 0,60.

Tabel 4.2

Uji Reliabilitas

\begin{tabular}{|c|c|c|c|c|}
\hline No. & Variabel & Cronbach's Alpha & N of Items & Keterangan \\
\hline 1 & Promosi & 0,714 & 10 & Reliabel \\
\hline 2 & Kualitas Pelayanan & 0,769 & 10 & Reliabel \\
\hline 3 & Kepuasan Konsumen & 0,841 & 10 & Reliabel \\
\hline
\end{tabular}

Sumber: Data primer yang diolah,2019

Berdasarkan Tabel 4.2 nilai cronbanch alpha menunjukkan hasil lebih besar dari 0,60, maka pernyataan yang digunakan dapat dikatakan reliabel. 


\subsection{Asumsi Klasik}

\subsubsection{Uji Normalitas}

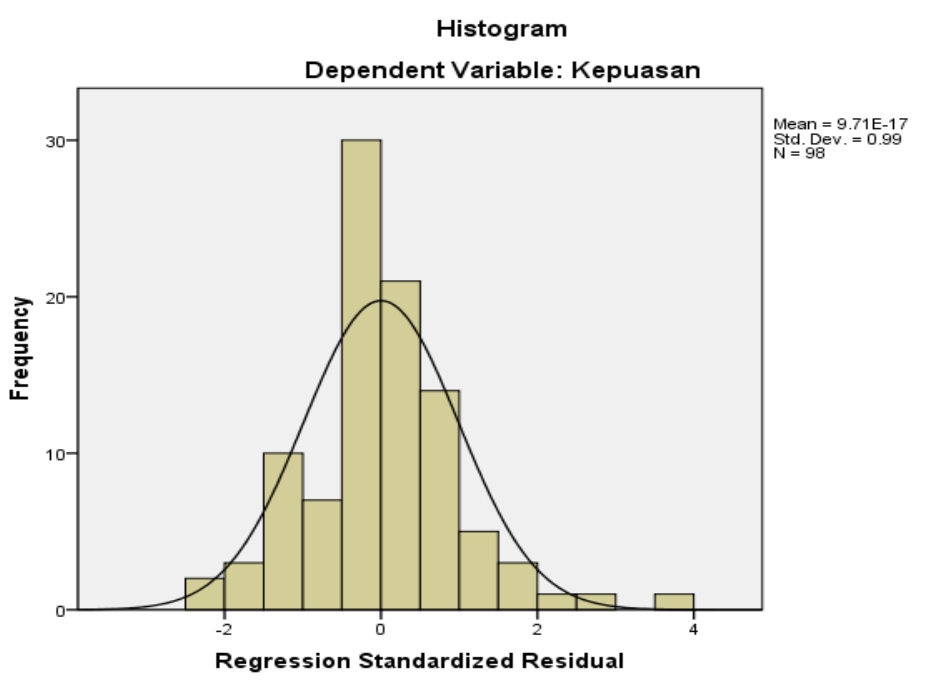

\section{Gambar 4.1}

Grafik Histogram

Sumber: Data primer yang diolah,2019

Gambar 4.1 menunjukkan garis kurva berbentuk simetri (U) dan tidak melenceng ke kiri maupun kanan, maka dapat dikatakan bahwa data berdistribusi normal.

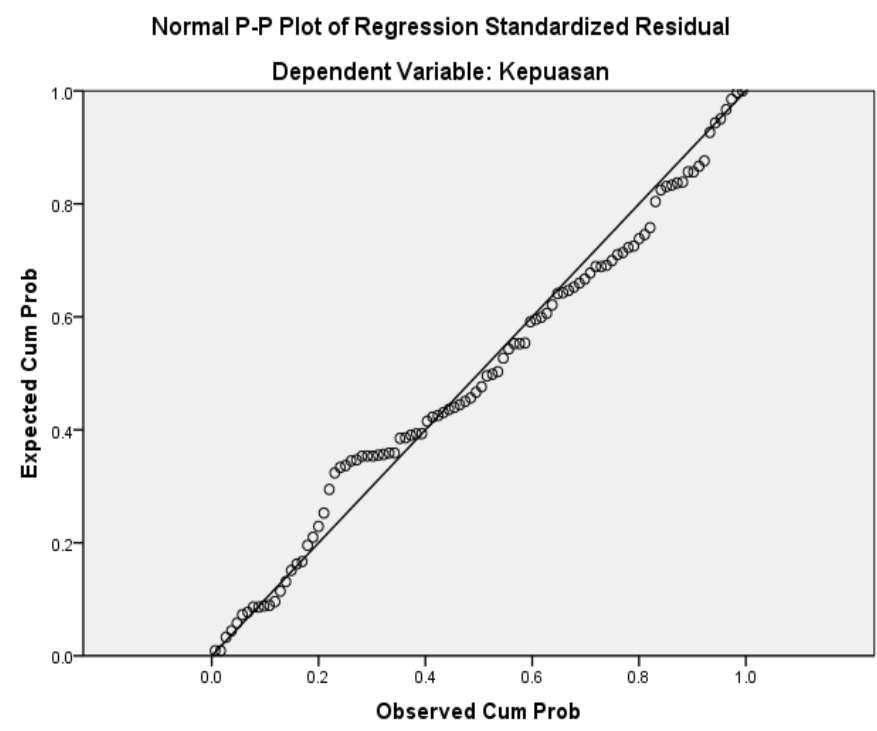

Gambar 4.2 
Uji normalitas juga dapat dilakukan dengan menggunakan grafik normal P-P Plot yang dapat dilihat pada Gambar 4.2, dimana titik-titik mendekati garis diagonal yang artinya data berdistribusi normal.

Pengujian normalitas data juga dilakukan dengan menggunakan alat uji statistik yaitu uji Kolmogorov Smirnov.

Tabel 4.3

Uji One Kolmogrov Smirnov

\begin{tabular}{|c|c|c|}
\hline & & Unstandardized Residual \\
\hline $\mathrm{N}$ & & 98 \\
\hline Normal Parameters ${ }^{\mathrm{a}, \mathrm{b}}$ & $\begin{array}{l}\text { Mean } \\
\text { Std. Deviation }\end{array}$ & $\begin{array}{r}.0000000 \\
5.15598900\end{array}$ \\
\hline Most Extreme Differences & Absolute & .098 \\
\hline & Positive & .069 \\
\hline & Negative & -.098 \\
\hline Kolmogorov-Smirnov Z & & .966 \\
\hline Asymp. Sig. (2-tailed) & & 308 \\
\hline
\end{tabular}

a. Test distribution is Normal.

b. Calculated from data.

Sumber: Data primer yang diolah,2019

Pada Gambar 4.3 menghasilkan nilai Asympy.Sig (2-tailed) sebesar 0,308 di atas tingkat signifikan 0,05, dengan demikian hasil uji normalitas Kolmogorov Smirnov dapat disimpulan bahwa data berdistribusi normal.

\subsubsection{Uji Multikolinearitas}

Uji multikolinearitas dilakukan untuk mengetahu.apakah terdapat hubungan linear antara variabel bebas. Untuk mengetahui ada tidaknya gejala multikolinearitas dapat dilihat dari besarnya nilai tolerance dan VIF (Variance Inflation Factor).

Tabel 4.4

Uji Multikolinearitas

\begin{tabular}{|c|c|c|c|}
\hline \multicolumn{4}{|c|}{ Coefficients $^{\mathrm{a}}$} \\
\hline \multirow{2}{*}{\multicolumn{2}{|c|}{ Model }} & \multicolumn{2}{|c|}{ Collinearity Statistics } \\
\hline & & Tolerance & VIF \\
\hline \multirow[t]{2}{*}{1} & Promosi & .888 & 1.126 \\
\hline & KualitasPelayanan & .888 & 1.126 \\
\hline
\end{tabular}

Sumber: Data primer yang diolah,2019

Nilai tolerance masing-masing variabel bebas yaitu promosi dan kualitas pelayanan sebesar 0,888 > 0,1 dan nilai VIF masing-masing variabel bebas yaitu promosi dan kualitas pelayanan sebesar $1,126<10$. Dengan demikian tidak terjadi multikolinearitas dalam penelitian ini. 


\subsubsection{Uji Heteroskedastisitas}

Model regresi yang baik adalah tidak terjadi heterokedastisitas.

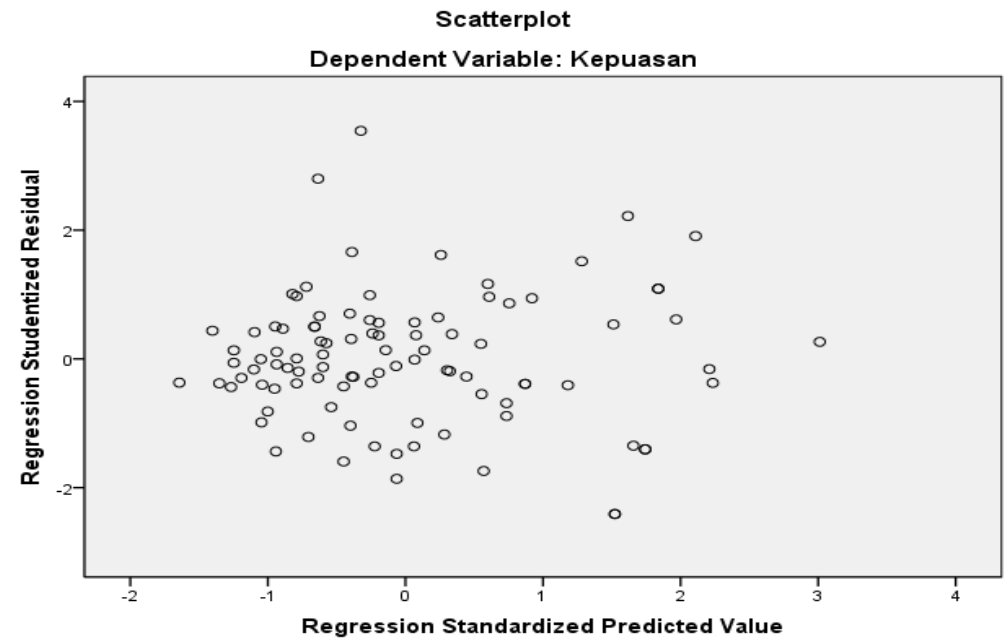

Gambar 4.3

Sumber: Data primer yang diolah,2019

Pada Gambar 4.3, Grafik Scatterplot terlihat bahwa titik-titik menyebar secara acak dengan tidak adanya pola yang jelas serta tersebar baik diatas maupun dibawah angka 0 pada sumbu Y. Dengan demikian, dapat disimpulkan bahwa tidak terjadi heterokedastisitas sehingga model ini layak dipakai untuk penelitian selanjutnya.

Hasil pengujian heteroskedastisitas dengan metode Gletjer.

Tabel 4.5

Coefficients $^{\mathbf{a}}$

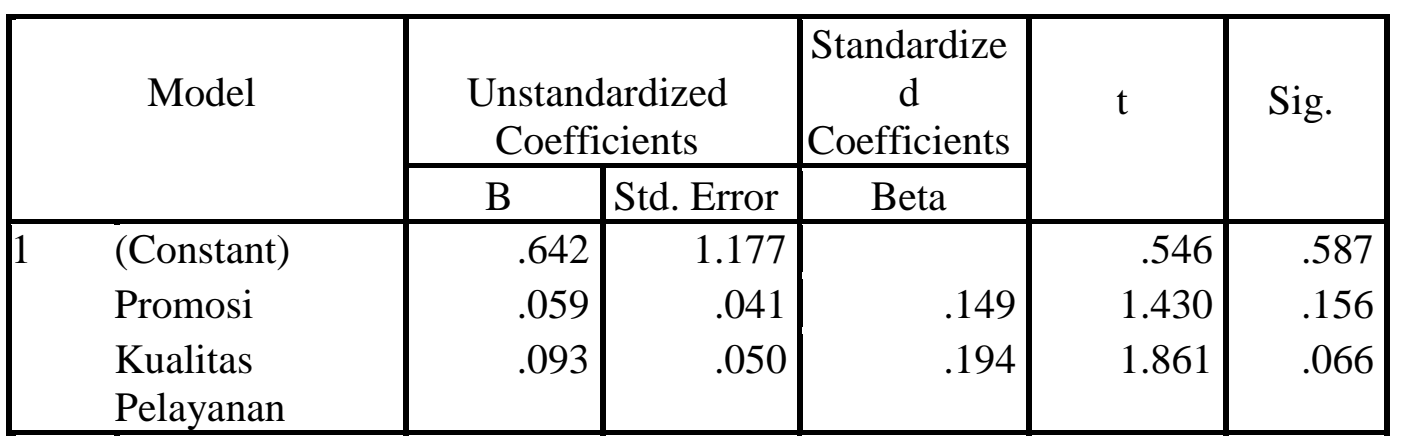

a. Dependent Variable: ABSUT

Sumber: Data primer yang diolah,2019

Pada Tabel 4.5, nilai signifikan dari promosi sebesar 0,156>0,05 dankualitas pelayanan sebesar 0,066 > 0,05 dengan demikian dari hasil uji Gletjer dapat dikatakan tidak terjadi masalah heteroskedastisitas. 


\subsection{Analisis Regresi Linear Berganda}

Pengujian hipotesis yang digunakan dalam penelitian adalah dengan menggunakan analisis regresi linier berganda.

\section{Tabel 4.6}

Hasil Regresi Linear Berganda

\begin{tabular}{|c|c|c|c|c|c|c|}
\hline & \multirow[t]{2}{*}{ Model } & \multicolumn{2}{|c|}{$\begin{array}{l}\text { Unstandardized } \\
\text { Coefficients }\end{array}$} & \multirow{2}{*}{$\begin{array}{c}\begin{array}{c}\text { Standardized } \\
\text { Coefficients }\end{array} \\
\text { Beta }\end{array}$} & \multirow[t]{2}{*}{$\mathrm{t}$} & \multirow[t]{2}{*}{ Sig. } \\
\hline & & B & $\begin{array}{l}\text { Std. } \\
\text { Error }\end{array}$ & & & \\
\hline 1 & $\begin{array}{l}\text { (Constant) } \\
\text { Promosi } \\
\text { Kualitas } \\
\text { Pelayanan }\end{array}$ & $\begin{array}{r}11.232 \\
.272 \\
.290\end{array}$ & $\begin{array}{r}.848 \\
.065 \\
.078\end{array}$ & $\begin{array}{l}.372 \\
.329\end{array}$ & $\begin{array}{l}6.079 \\
4.170 \\
3.694\end{array}$ & $\begin{array}{l}.000 \\
.000 \\
.000\end{array}$ \\
\hline
\end{tabular}

Sumber: Data primer yang diolah,2019

\section{Kepuasan $=11.232+$ 0,272 Promosi + 0,290 Kualitas Pelayanan}

Berdasarkan Tabel 4.6 maka persamaan regresi linier berganda diatas adalah:

a. Konstanta $=11,232$

Jika promosi dan kualitas pelayanan tidak mengalami peningkatan sebesar satu satuan (tetap) maka kepuasan konsumen adalah sebesar 11,232 satuan.

b. Promosi $=0,27$

Koefisien regresi promosi sebesar 0,272 dan bermilai positif, hal ini menyatakan bahwa setiap kenaikan promosi satu satuan akan meningkatkan kepuasan konsumen sebesar 0,272 satuan dengan anggapan variabel lainnya tetap.

c. Kualitas pelayanan $=0,290$

Koefisien regresi kualitas pelayanan sebesar 0,290 dan bernilai positif, hal ini menyatakan bahwa setiap kenaikan kualitas pelayanan 1 satuan akan menyebabkan kenaikan kepuasan konsumen sebesar 0,290 satuan dengan anggapan variabel lainnya tetap.

\subsection{Koefisien Determinasi}

Nilai koefisien determinasi yang kecil berarti kemampuan variabel-variabel independen dalam menjelaskan variasi variabel dependen amat terbatas.

Tabel 4.7

Model Summary ${ }^{\mathrm{b}}$

\begin{tabular}{|c|r|r|r|r|}
\hline Model & R & R Square & \multicolumn{1}{|c|}{$\begin{array}{c}\text { Adjusted R } \\
\text { Square }\end{array}$} & $\begin{array}{c}\text { Std. Error of the } \\
\text { Estimate }\end{array}$ \\
\hline dimension0 1 & $.574^{\mathrm{a}}$ & .329 & .315 & 5.210 \\
\hline
\end{tabular}

a. Predictors: (Constant), Promosi, KualitasPelayanan

b. Dependent Variable: Kepuasan

Sumber: Data primer yang diolah,2019

Pada Tabel 4.7 hasil uji koefisien determinasi diperoleh nilai Adjusted RSquare sebesar 0,315 hal ini berarti 31,5\% dari variasi variabel dependen yaitu kepuasan konsumen yang dapat dijelaskan oleh variasi variabel independen promosi dan kualitas pelayanan 
sedangkan sisanya sebesar $68,5 \%$ dijelaskan oleh variabel lain yang tidak diteliti pada penelitian ini, seperti harga, citra merek dan sebagainya.

\subsection{Uji F}

Tabel 4.8

ANOVA ${ }^{b}$

\begin{tabular}{|c|c|c|c|c|c|c|}
\hline \multicolumn{2}{|c|}{ Model } & $\begin{array}{l}\text { Sum of } \\
\text { Squares }\end{array}$ & $\mathrm{df}$ & $\begin{array}{l}\text { Mean } \\
\text { Square }\end{array}$ & $\mathrm{F}$ & Sig. \\
\hline \multirow[t]{3}{*}{1} & Regression & 1264.024 & 2 & \multirow{3}{*}{$\begin{array}{r}632.012 \\
27.144\end{array}$} & \multirow[t]{3}{*}{23.284} & \multirow[t]{3}{*}{$.000^{\mathrm{a}}$} \\
\hline & Residual & 2578.670 & 95 & & & \\
\hline & Total & 3842.694 & 97 & & & \\
\hline
\end{tabular}

a. Predictors: (Constant), Pormosi, Kualitas Pelayanan

b. Dependent Variable: Kepuasan

Sumber: Data primer yang diolah,2019

Berdasarkan Tabel 4.8 uji signifikansi simultan menghasilkan nilai $F_{\text {hitung }}$ sebesar 23.284, pada derajat bebas $1\left(d f_{1}\right)=k-1=3-1=2$, dan derajat bebas $2\left(d f_{2}\right)=n-k=98-3=95$, dimana $n=$ jumlah sampel, $k=$ jumlah variabel, maka nilai $F_{\text {tabel }}$ pada taraf kepercayaan signifikansi 0,05 adalah 3,09 dengan demikian dari hasil perhitungan SPSS diperoleh nilai $F_{\text {hitung }}(23,284)>F_{\text {tabel }}(3,09)$ dengan tingkat signifikansi $0,000<0,05$. Hal ini berarti bahwa Ho ditolak dan Ha diterima yaitu secara simultan Promosi dan kualitas pelayanan berpengaruh secara positif dan signifikan terhadap kepuasan konsumen PT.Hamsa Tour and Travel.

\subsection{Uji t}

\section{Tabel 4.9}

\begin{tabular}{|c|c|c|c|c|c|c|}
\hline \multirow{2}{*}{\multicolumn{2}{|c|}{ Model }} & \multicolumn{2}{|c|}{$\begin{array}{l}\text { Unstandardized } \\
\text { Coefficients }\end{array}$} & \multirow{2}{*}{$\begin{array}{c}\begin{array}{c}\text { Standardized } \\
\text { Coefficients }\end{array} \\
\text { Beta }\end{array}$} & \multirow[t]{2}{*}{$\mathrm{t}$} & \multirow[t]{2}{*}{ Sig. } \\
\hline & & B & $\begin{array}{l}\text { Std. } \\
\text { Error }\end{array}$ & & & \\
\hline 1 & $\begin{array}{l}\text { (Constant) } \\
\text { Promosi } \\
\text { Kualitas } \\
\text { Pelayanan }\end{array}$ & $\begin{array}{r}11.232 \\
.272 \\
.290\end{array}$ & $\begin{array}{r}1.848 \\
.065 \\
.078\end{array}$ & $\begin{array}{l}.372 \\
.329\end{array}$ & $\begin{array}{l}6.079 \\
4.170 \\
3.694\end{array}$ & $\begin{array}{l}.000 \\
.000 \\
.000\end{array}$ \\
\hline
\end{tabular}

Sumber: Data primer yang diolah,2019

Pada Tabel 4.9, nilai $t_{\text {tabel }}$ untuk probabilitas 0,05 pada derajat bebas $(d f)=98-2=96$ adalah sebesar 1,984. Dengan demikian hasil dari uji parsial dapat dijelaskan sebagai berikut:

1. Hasil pengujian hipotesis secara parsial untuk variabel promosi diperoleh nilai $t_{\text {hitung }}$ sebesar 4,170 lebih besar $t_{\text {tabel }}$ sebesar 1,985 dan dengan nilai signifikan sebesar $0,000<0,05$ maka dapat disimpulkan bahwa $\mathrm{H}_{0}$ ditolak dan $\mathrm{H}_{\mathrm{a}}$ diterima yaitu secara parsial Promosi berpengaruh secara positif dan signifikan terhadap kepuasan konsumen PT. Hamsa Tour and Travel. 
2. Hasil pengujian hipotesis secara parsial untuk variabel kualitas pelayanan diperoleh nilai thitung sebesar 3,694 lebih besar $t_{\text {tabel }}$ sebesar 1,985 dan dengan nilai signifikan sebesar $0,000<0,05$ maka dapat disimpulkan bahwa Ho ditolak dan Ha diterima yaitu secara parsial kualitas pelayanan berpengaruh secara positif dan signifikan terhadap kepuasan konsumen PT. Hamsa Tour and Travel.

\section{KESIMPULAN DAN SARAN}

\section{Kesimpulan}

Kesimpulan dari hasil penelitian ini adalah sebagai berikut :

1. Hasil pengujian secara parsial menunjukkan bahwa Promosi berpengaruh secara positif dan signifikan terhadap kepuasan konsumen PT. Hamsa Tour and Travel. Hal ini terlihat dari nilai $\left.t_{\text {hitung }}\right\rangle t_{\text {tabel }}$ yaitu $4,170>1,985$ dan dengan nilai signifikan sebesar $0,000<0,05$.

2. Hasil pengujian secara parsial menunjukkan bahwa kualitas pelayanan berpengaruh secara positif dan signifikan terhadap kepuasan konsumen PT.Hamsa Tour and Travel terlihat dari $t_{\text {hitung }}>t_{\text {tabel }}$ yaitu 3,694 $>1,985$ dan dengan nilai signifikan sebesar $0,000<0,05$.

3. Hasil pengujian secara simultan menunjukkan bahwa Promosi dan kualitas pelayanan berpengaruh secara positif dan signifikan terhadap kepuasan konsumen PT.Hamsa Tour and Travel. Hal tersebut dapat dilihat dari nilai $F_{\text {hitung }}(23,284)$ $>F_{\text {tabel }}(3,07)$ dengan tingkat signifikansi $0,000<0,05$. Hasil uji koefisien determinasi diperoleh nilai Adjusted RSquare sebesar 0,315 hal ini berarti 31,5\% dari variasi variabel dependen yaitu kepuasan konsumen yang dapat dijelaskan oleh variasi variabel independen promosi dan kualitas pelayanan sedangkan sisanya sebesar $68,5 \%$ dijelaskan oleh variabel lain yang tidak diteliti pada penelitian ini, seperti harga, citra merek dan sebagainya.

\section{Saran}

Saran-saran yang berguna dari hasil penelitian ini adalah :

1. Bagi peneliti

Sebagai bahan saran untuk memperluas wawasan penelitian dalam bidang ilmu manajemen pemasaran

2. Bagi peneliti selanjutnya

Disarankan untuk menambah variabel lain di luar dari variabel yang diteliti oleh peneliti seperti : harga, citra merek, dan sebagainya.

3. Bagi PT.Hamsa Tour and Travel

Kepuasan konsumen secara keseluruhan sangat dipengaruhi oleh promosi dan kualitas pelayanan. Peningkatan kedua variabel tersebut baik secara terpisah (parsial) maupun bersama-sama (simultan) dapat meningkatkan keputusan pembelian. Maka disarankan agar perusahaan dapat meningkatkan dan memperbaiki kedua variabel tersebut kepada pelanggan sehingga dapat meningkatkan kepuasan pelanggan pada perusahaan.

4. Bagi Universitas Prima Indonesia

Sebagai tambahan jumlah hasil karya mahasiswa yang dapat menjadi referensi bagi Fakultas Ekonomi Manjemen, Universitas Prima Indonesia (UNPRI). 


\section{DAFTAR PUSTAKA}

Abdullah, Thamrin dan Francis Tantri. 2015. Manajemen Pemasaran. Jakarta: PT. Rajagrafindo Persada.

Abdurrahman, Herdiana, Nana. 2015. Manajemen Strategi Pemasaran. Bandung : Pustaka Setia.

Adam, Muhammad. 2015. Manajemen Pemasaran Jasa Teori dan Aplikasi.Bandung : Alfabeta.

Alma, Buchari. 2016. Manajemen Pemasaran dan Pemasaran Jasa. Bandung : Alfabeta.

Arikunto, Suharsimi. 2014. Prosedur Penelitian Suatu Pendekatan. Jakarta : Rineka Cipta.

Bangun.2016. Pengaruh Kualitas Produk dan Pelayanan terhadap Loyalitas Pelanggan pada PT. ANgsana Ciptra Pratama.Jurnal.

Ebert, Ronald J dan Ricky W. Griffin. 2015. Pengantar Bisnis. Edisi Kesepuluh. Jakarta: PT. Gelora Aksara Pratama.

Ghozali, Imam. 2016. Aplikasi Multivariate Dengan Program IBM SPSS 23. Semarang : Universitas Diponegoro.

Hasan, Ali. 2013. Marketing dan Kasus-kasus Pilihan. Cetakan Kesatu. Yogyakarta : CAPS (Center for Academic Publishing Service).

Kurniansih.2012. Pengaruh Harga dan Kualitas Pelayanan terhadap Loyalitas Pelanggan Melalui Variabel Kepuasan (Studi pada Benkel Ahass 0003-Astra Motor Siliwangi Semarang pada PT. Astra Internasional Tbk-HSO Cabang Semarang).Jurnal.

Limakrisna, Nandan, Susilo. 2012. Manajemen Pemasran teori dan Aplikasi dalam Bisnis.Jakarta : Mitra Wacana Media.

Prasetyo. 2014. Pengaruh Kualitas Pelayanan, Promosi dan Kepuasan terhadap Loyalitas pelanggan (Studi Pada Swalayan Luwes Purwodadi ). Jurnal.

Sangadji, Mamang, Etta, Sopiah. 2016. Perilaku Konsumen Pendekatan Praktis Disertai Himpunan Jurnal Penelitian. Ed.1, Yogyakarta : Andi Offset.

Sunyoto, Danang. 2013. Teori, Kuesioner dan Analisi Data untuk Pemasaran dan Perilaku Konsumen. Cetakan Kesatu. Yogyakarta :Center for Academic Publishing Service.

--------. 2014. Konsep Dasar Riset Pemasaran dan Perilaku Konsumen.Yogyakarta :Center for Academic Publishing Service. 
Surjaweni, Wiratna, V. 2014. SPSS Untuk Penelitian. Yogyakarta : Pustaka Baru Press..

-------. 2015. Metodologi Penelitian - Bisnis \& Ekonomi. Yogyakarta : Pustaka Baru Press.

Suryabrata. 2013. Statistik untuk Penelitian. Bandung : Alfabeta.

Tjiptono, Fandy. 2008. Strategi Pemasaran..Yogyakarta : ANDI Offset.

Tjiptono, Fandy, Gregorius Chandra. 2012. Pemasaran Strategi. Ed 2.Yogyakarta : ANDI OFFSET.

Yuniarti, Sri, Vinna. 2015. Perilaku Konsumen Teori dan Praktek. Cetakan Kesatu. Bandung : Pustaka Setia.

Zulganef.2013.Metode Penelitian Sosial dan Bisnis. Yogyakarta : Graha Ilmu 